www.jmscr.igmpublication.org

Index Copernicus Value: 79.54

ISSN (e)-2347-176x ISSN (p) 2455-0450

crossrefDOI: https://dx.doi.org/10.18535/jmscr/v7i3.119

\title{
Clinical Study of Locally Advanced Breast Cancer and Management
}

\section{Dr P. Mythili General Surgery (MS) ${ }^{1}$, Dr G. Santosh Kumar General Surgery (P.G) ${ }^{2}$ Dr P. Jyothi Sree General Surgery (P.G) ${ }^{3}$, Dr G. Keerthi General Surgery (P.G) ${ }^{4}$}

\begin{abstract}
To study the clinical presentation, its age distribution of locally advanced breast carcinoma and its various modes of management.

Keywords: Locally advanced breast cancer, modified radical mastectomy, neo adjuvant chemotherapy, quadrantectomy, axillary dissection, radiotherapy.
\end{abstract}

\section{Introduction}

Worldwide breast cancer is the most frequent cancer in women and represents the 2nd leading cause of cancer death among women. locally advanced breast cancer constitutes more than 50 to $70 \%$ of the patients presenting for treatment. Have 2 common problems in treatment. Achieving local control and prolonging survival by preventing or delaying distant metastasis. Today treatment of $\mathrm{LABC}$ requires a combination of systemic and local/regional therapies.

\section{Materials and Methods}

The present study includes 50 patients who attended dept of general surgery AMC, Visakhapatnam during period of November 2013 to October 2015.

\section{Inclusion Criteria}

All patients presenting in AMC, Visakhapatnam with stage IIIA, IIIB, IIIC and inflammatory carcinoma were included in the study.

\section{Exclusion Criteria}

Patients who were clinically diagnosed as having locally advanced breast cancer but on investigations found to have distant metastasis were excluded.

Diagnosis was made by FNAC, investigative profile available and accessible in the hospital were made use of.

Investigations to rule out metastasis were obtained.USG abdomen and pelvis, LFT, Chest Xray and skeletal $\mathrm{X}$-rays were done.

The multimodality treatment approach of LABC commenced in majority of cases with neoadjuvant chemotherapy, followed by local therapy in the form of MRM (Auchincloss modification).

In certain cases of stage IIIA disease considered operable at presentation (stage $\mathrm{T} 3 \mathrm{~N} 1$ ) treatment is initiated with local therapy i.e modified radical mastectomy followed by adjuvant chemotherapy with standard chemotherapy regimen.

The response to neoadjuvant chemotherapy was studies by serial clinical examination noting the regression in the size of the lump (or ulcer) and change in the lymph node status of axilla. 
Results

Table 1: Age distribution

\begin{tabular}{|l|c|c|}
\hline AGE GROUP & NUMBER OF PATIENTS & PERCENTAGE \\
\hline $21-30$ YRS & 6 & $12 \%$ \\
\hline $31-40 Y R S$ & 13 & $26 \%$ \\
\hline $41-50$ YRS & 17 & $34 \%$ \\
\hline $51-60 Y R S$ & 9 & $18 \%$ \\
\hline$>6$ OYRS & 5 & $10 \%$ \\
\hline
\end{tabular}

Table 2: Tumour size

\begin{tabular}{|l|c|c|}
\hline TUMOUR SIZE & NUMBER OF PATIENT & PERCENTAGES \\
\hline$<5$ CMS & 7 & $14.2 \%$ \\
\hline $5-8 \mathrm{CMS}$ & 37 & $75.5 \%$ \\
\hline $8-10 \%$ & 4 & $8.2 \%$ \\
\hline$>10 \mathrm{CMS}$ & 1 & $2 \%$ \\
\hline
\end{tabular}

Table 3: Fixity to skin and chest wall

\begin{tabular}{|l|c|c|c|}
\hline Fixity & Feature & Number of patients & Percentage \\
\hline \multirow{3}{*}{ Skin } & Peau d orange & 12 & $24 \%$ \\
\cline { 2 - 4 } & Ulcer & 8 & $16 \%$ \\
\cline { 2 - 4 } & Sat nodule & 4 & $8 \%$ \\
\hline Chest wall & & 5 & $10 \%$ \\
\hline
\end{tabular}

Table 4: lymph node status

\begin{tabular}{|l|c|c|}
\hline Lymph node status & Number of patients & Percentage \\
\hline N1 & 26 & $52 \%$ \\
\hline N2 & 22 & $44 \%$ \\
\hline N3 & 2 & $4 \%$ \\
\hline
\end{tabular}

Table 5: Stage of Disease

\begin{tabular}{|c|c|c|c|c|}
\hline GROUP STAGE & TNM STAGE & $\begin{array}{l}\text { NUMBER OF } \\
\text { PATIENTS }\end{array}$ & $\begin{array}{l}\text { NUMBER OF } \\
\text { PATIENTS }\end{array}$ & PERCENTAGE \\
\hline \multirow{3}{*}{ IIIA } & T3N1M0 & 12 & \multirow{3}{*}{23} & \multirow{3}{*}{$46 \%$} \\
\hline & T3N2M0 & 10 & & \\
\hline & T2N2 & 1 & & \\
\hline \multirow{4}{*}{ IIIB } & T4a N1 M0 & 1 & \multirow{4}{*}{24} & \multirow{4}{*}{$48 \%$} \\
\hline & T4a N2 M0 & 4 & & \\
\hline & T4b N1 M0 & 13 & & \\
\hline & T4b N2 M0 & 6 & & \\
\hline IIIC & T3N3M0 & 2 & 2 & $4 \%$ \\
\hline INFLAMMATORY Ca & $\mathrm{T} 4 \mathrm{~d}$ & 1 & 1 & $2 \%$ \\
\hline
\end{tabular}

Table 6: Proportion of Inoperable Cases

\begin{tabular}{|l|c|c|}
\hline OPERABILITY & NUMBER & PERCENTAGE \\
\hline OPERABLE & 12 & $24 \%$ \\
\hline INOPERABLE & 38 & $76 \%$ \\
\hline
\end{tabular}

Table 7: Sequencing of Treatment

\begin{tabular}{|l|c|c|}
\hline SEQUENCING & NUMBER OF CASES & PERCENTAGE \\
\hline $\mathrm{NC}+\mathrm{S}+\mathrm{C}+\mathrm{R}$ & 33 & $66 \%$ \\
\hline $\mathrm{NC}+\mathrm{S}+\mathrm{C}$ & 2 & $4 \%$ \\
\hline $\mathrm{NC}+\mathrm{R}$ & 3 & $6 \%$ \\
\hline $\mathrm{S}+\mathrm{C}+\mathrm{R}$ & 7 & $14 \%$ \\
\hline $\mathrm{S}+\mathrm{C}$ & 5 & $10 \%$ \\
\hline
\end{tabular}


Table 8: Chemotherapy Regimen

\begin{tabular}{|l|c|c|}
\hline REGIMEN & NUMBER OF PATIENTS & PERCENTAGE \\
\hline CMF & 26 & $52 \%$ \\
\hline $\mathrm{AC}$ & 24 & $48 \%$ \\
\hline
\end{tabular}

Table 9: Response to Neo Adjuvant Chemotherapy

\begin{tabular}{|l|c|c|c|c|}
\hline \multicolumn{2}{|l|}{ CLINICAL RESPONSE } & IIIA & IIIB & IIIC \\
\hline $\begin{array}{l}\text { COMPLET } \\
\text { E(Ccr) }\end{array}$ & $100 \%$ & 3 & 2 & - \\
\hline \multirow{4}{*}{ Partial } & $91-99 \%$ & 2 & 1 & - \\
\cline { 2 - 5 } & $81-90 \%$ & 1 & 5 & 1 \\
\cline { 2 - 5 } & $71-80 \%$ & 3 & 8 & - \\
\cline { 2 - 5 } & $61-70 \%$ & - & 2 & 1 \\
\cline { 2 - 5 } & $51-60 \%$ & - & 1 & - \\
\hline \multirow{3}{*}{$\begin{array}{l}\text { STABLE } \\
\text { DISEASE }\end{array}$} & $1-50 \%$ & 2 & 2 & - \\
\cline { 2 - 6 } & $0 \%$ & - & 3 & - \\
\hline
\end{tabular}

Table 10: Chemotherapy Toxicity

\begin{tabular}{|l|c|c|c|c|}
\hline \multirow{2}{*}{ TOXICITY } & \multicolumn{2}{|c|}{ CMF } & \multicolumn{2}{c|}{ AC } \\
\cline { 2 - 5 } & NUMBER & PERCENTAGE & NUMBER & PERCENTAGE \\
\hline ALLOPECIA & 10 & $38.46 \%$ & 20 & $83.33 \%$ \\
\hline ANEMIA & 5 & $19.2 \%$ & 6 & $25 \%$ \\
\hline MUCOSITIS & 4 & $15.4 \%$ & 3 & $12.5 \%$ \\
\hline NAUSEA & 1 & $3.8 \%$ & 5 & $20.8 \%$ \\
\hline EMESIS & 3 & $11.5 \%$ & 9 & $37.5 \%$ \\
\hline FATIGUE & 2 & $7.7 \%$ & 4 & $16.6 \%$ \\
\hline NEUTROPENIA & 0 & $0 \%$ & 1 & $4.1 \%$ \\
\hline
\end{tabular}

\section{Outcome}

The patients were regularly followed up and at the end of the study $35(70 \%)$ of the patients were doing well. $4(8 \%)$ of the patients developed distant metastatis and $3(6 \%)$ of the patients developing local recurrence. 8 (16\%) of the patients were lost follow up.

\section{References}

1. Rosai J. Breast. Rosai and Ackerman,,s Surgical Pathology. 9th ed: Missouri. Elsevier; 2004. 1763-1827.

2. Tavassoli FA, Devilee P. WHO classification of tumours- Pathology and genetics tumours of the breast and female genital organs. Lyon: International agency for research on cancer (IARC press); 2003.

3. Moses Ambroise, Mitra Ghosh, VS Mallikarjuna, Ann Kurian. Immunohistochemical Profile of Breast
Cancer Patients at a Tertiary Care Hospital in South India. Asian Pacific J Cancer Prev, 12, 625-629

4. Lester SC. The Breast. In: Kumar V, Abbas AK, Fausto N, Aster JC editors. Robbins and Cotran Pathologic Basis of Disease. 8th ed. Philadelphia: Elsevier; 2010, 1073-90.

5. Guidelines for management of breast cancer/by WHO Regional Office for the Eastern Mediterranean: EMRO Technical Publications Series; 31.

6. Kyle Bradley T. Prognostic and predictive markers in breast carcinoma. CAP Cancer Committee 2007.

7. Almasri NM, Hamad MA. Immunohistochemical evaluation of human epidermal growth factor receptor 2 and estrogen and progesterone receptors in breast carcinoma in Jordan. Breast Cancer Research 2005; 7: 
598-604.

8. Jambhekar N, Chaturvedi AC, Madur BP. Immunohistochemistry in surgical pathology practice: A current perspective of simple, powerful, yet complex tool. IJPM 2008; 51(1): 2- 12

9. Azizun-Nisa,Yasmin Bhurgri, Farrukh Raza, Naila kayani. Comparison of ER/PR and her2 reactivity pattern with histolgic grade, tumor size and lymph node status in breast cancer Asian pacific J cancer 9,553556. 